\title{
The quality of the microclimate in educational buildings subjected to thermal modernization
}

\author{
Anna Lis ${ }^{1, *}$, and Nadiia Spodyniuk $^{2}$ \\ ${ }^{1}$ Czestochowa University of Technology, Faculty of Civil Engineering, ul. Akademicka 3, \\ 42-201 Czestochowa, Poland \\ ${ }^{2}$ National Technical University of Ukraine "Igor Sikorsky Kyiv Polytechnic Institute", Metal Science \\ and Heat Treatment Department, 35 Politechnichna str., Kyiv, 03056, Ukraine
}

\begin{abstract}
Realization and exploitation of buildings involves in European Union about $40 \%$ of total energy consumption [1]. One of the elements of rationalization of energy consumption in buildings are the undertakings related with thermal modernization of buildings. The actions related with reducing the energy intensity of buildings are not always correlated with improvement of microclimate conditions in the rooms. Errors in the implementation of the energy efficiency program led to the phenomenon of sick building syndrome. The paper presents the results of the research conducted in a few educational buildings before and after thermal modernization. The research includes energy consumption for the heating of building and selected parameters of the interior microclimate. This analysis was carried out to evaluate the influence of energy saving activities on microclimate interior conditions. It was found that in many cases commonly used gravitational ventilation is not able to ensure the proper conditions of the interior microclimate, and the concentrations of carbon dioxide recorded in the tested rooms exceeded the applicable standards.
\end{abstract}

\section{Introduction}

The issues of thermal protection of buildings are directly related with energy savings but also with other aspects. The purpose of thermal protection is also to ensure appropriate indoor microclimate conditions and thermal comfort of occupants. The rationalization of energy consumption is a widely addressed issue in strategic documents determining the development direction of the European Union [2, 3]. All members of the Union committed to elaborate national, long-term strategies supporting the modernization investments covering the specification of optimal ways for improving energy efficiency of buildings and specification of instruments mobilising the investments. Starting from 2021 all newly constructed buildings will be required to have very low energy consumption, covered mainly by the renewable energy resources.

Presently building stock of European Union covers about 200 million buildings, out of which 6 million are located in Poland. Buildings existing in Poland, both residential and public are characterized by a great potential in terms of energy efficiency. The main element

* Corresponding author: alis@bud.pcz.pl 
of improving their energy efficiency are the thermal modernization activities, which adapts existing buildings to present and future energy requirements. It has been estimated that through the modernization of an average building in accordance with the currently valid regulations up to $40-50 \%$ of energy may be saved [5]. However, according to the European Union Directive on the energy performance of buildings [4], it is important not only to improve the energy efficiency of buildings, but also to define the conditions for the classification of objects in terms of the indoor microclimate requirements.

The energy saving activities focusing only on the insulation of building envelope and air tightness of fenestration joinery often results in worsening of the microclimate quality. Excessive airtightness of buildings often leads to improper operation of natural ventilation systems and impaired air quality. High concentration of pollutants in the air inside the rooms is usually the reason for occurring a sick building syndrome. Requirements relating to ensuring the proper state of the indoor environment in buildings should be therefore given priority in relation to the requirements of energy saving due to the need to ensure first of all the right conditions for people to stay in closed rooms.

The evaluation of influence of thermal modernization activity on indoor microclimate conditions was conducted for an educational buildings. The lack of thermal insulation in building envelope caused mainly that the buildings failed to comply with thermal protection requirements and were not energy efficient therefore generating considerable energy losses. Thermal modernization of buildings consisted of insulation of building envelope and modernization of the heating system and hot water preparation.

\section{The formation of microclimate conditions in buildings}

The elements that affect the human are both thermal parameters of the microclimate as well as chemical, microbiological pollutants and air ionization and also ionizing and non-ionizing radiation, lighting and noise [6]. Long-term influence of disadvantageous of environmental conditions may cause or exacerbate many symptoms associated with abnormal functioning of the organism, lead to the depletion of mental and physical efficiency as well as to weakness or illness. As people spend a considerable amount of time indoors, buildings should be a structure that will not have a negative impact on them. However, the World Health Organization already in 1983 found that many of the disease symptoms to which users complain relate to the quality of the indoor environment [6]. The attention was paid to the relationship between indoor environmental quality and increasing sickness absence and its high economic cost $[7,8]$. This phenomenon is called the sick building syndrome (SBS), and its symptoms appear to be closely linked to time spent in the building and decrease or disappear after leaving it [9]. Symptoms of the syndrome are primarily eye, nose or throat irritation, itching and dry skin, hoarseness and dry cough, cold and flu-like symptoms, dizziness and headache, nausea, sensitivity to odours, allergies and increased incidence of asthma attacks or fatigue, irritability and difficulty in concentration. The World Health Organization presented guidelines for the protection of health against many substances commonly found in indoor air [10-12].

The amount of air exchanged in the ventilation process has a large impact on the quality of the indoor environment, but also on the heat consumption, especially at high thermal insulation of the building envelope [13]. Errors in the implementation of the energy efficiency program, increasing the tightness of buildings and inadequate ventilation, but also the state of the external environment often results in worsening of the microclimate quality and the intensification of the syndrome phenomenon in modernized and new energy-saving buildings [14-16]. Particularly noticeable is deterioration of air quality in the rooms, the increase of its relative humidity and the occurrence of different kinds of moulds and fungus. 
Keeping the required values of microclimate parameters has obviously a significant influence on the building energy needs. Their level is mainly affected by the air temperature maintained in the rooms. Requirements regarding air temperatures to be maintained in individual rooms are included in the technical conditions [17]. Maintaining a lower temperature value promotes the energy efficiency. Lowering the value of air temperature from 20 to 18 degrees causes the reduction in heat demand by about $12 \%$, but it is not favourable for people working in a sitting position [18]. The ambient radiation temperature is related mainly to the temperature of the building envelope, which is affected by their thermal insulation. In the perfectly clean air, the low relative humidity is not burdensome for users of the rooms. Signalized health problems at low relative humidity are associated with indoor air pollution. High humidity is unfavourable due to energy saving and the possibility of mould and fungus growth.

At an air temperature of $20-22^{\circ} \mathrm{C}$, the recommended air velocity is $0.15-0.20 \mathrm{~m} / \mathrm{s}$, for people working in a sitting position. Research conducted by Fanger [19] showed that these values are too high. About $20 \%$ of respondents reported dissatisfaction with existing environmental conditions in the rooms.

\section{Improving the energy efficiency of educational buildings}

The buildings, in which the research was conducted, failed to comply with thermal protection requirements and were not energy efficient. In the years 2006-2012, they were subjected to thermal modernization. As part of the thermal modernization the insulation of building envelope and replacement of windows and external doors were made. Various changes in the heating and hot water preparation system in individual buildings were made too. First of all, the boiler room was modernized, coal or gas boilers were exchanged for devices with better efficiency provided with weather automation system. In the buildings after thermal modernization, the gravity ventilation system was left.

The heat transfer coefficients for walls, roofs, ceilings above basements, floors on the ground, windows and doors were calculated based on project data. The values of coefficients before and after thermal modernization are presented in Table 1.

Table 1. Heat transfer coefficients before and after thermal modernization.

\begin{tabular}{|c|c|c|c|c|}
\hline $\begin{array}{c}\text { Heat transfer coefficient, } \\
\left.\mathbf{W} / \mathbf{m}^{\mathbf{2}} \mathbf{K}\right)\end{array}$ & \multicolumn{2}{|c|}{ Before thermal modernization } & \multicolumn{2}{c|}{ After thermal modernization } \\
\cline { 2 - 5 } & $\begin{array}{c}\text { Harmonic } \\
\text { mean }\end{array}$ & $\begin{array}{c}\text { Standard } \\
\text { deviation }\end{array}$ & $\begin{array}{c}\text { Harmonic } \\
\text { mean }\end{array}$ & $\begin{array}{c}\text { Standard } \\
\text { deviation }\end{array}$ \\
\hline Walls & 1.35 & 0.22 & 0.22 & 0.02 \\
\hline Roofs & 0.96 & 0.23 & 0.16 & 0.03 \\
\hline Ceilings above basements & 1.21 & 0.15 & 0.33 & 0.06 \\
\hline Floors on the ground & 0.88 & 0.10 & 0.35 & 0.04 \\
\hline Windows & 2.6 & 0 & 1.3 & 0.2 \\
\hline Doors & 3.1 & 1.8 & 1.8 & 0.3 \\
\hline
\end{tabular}

Before the thermal modernization, the building envelope of the buildings had low thermal insulation. This resulted in excessive heat losses and was not conducive to energy saving. After insulation, the thermal parameters of the building envelope has significantly improved and the thermal insulation requirements applicable then were met.

Analyzing the energy parameters of buildings, the indicator of the annual demand for usable energy (EU), final energy (EK) and primary energy (EP) as well as the energy consumption index in relation to surface with adjustable temperature $\left(\mathrm{Q} / \mathrm{A}_{\mathrm{f}}\right)$ were determined. The energy parameters of buildings before and after thermal modernization are presented in Table 2. 
Table 2. Energy parameters of buildings before and after thermal modernization.

\begin{tabular}{|c|c|c|c|c|}
\hline \multirow{2}{*}{$\begin{array}{c}\text { Indicator, } \\
\mathbf{k W h} /\left(\mathbf{m}^{\mathbf{2}} \text { year) }\right.\end{array}$} & \multicolumn{2}{|c|}{ Before thermal modernization } & \multicolumn{2}{c|}{ After thermal modernization } \\
\cline { 2 - 5 } & $\begin{array}{c}\text { Harmonic } \\
\text { mean }\end{array}$ & $\begin{array}{c}\text { Standard } \\
\text { deviation }\end{array}$ & $\begin{array}{c}\text { Harmonic } \\
\text { mean }\end{array}$ & $\begin{array}{c}\text { Standard } \\
\text { deviation }\end{array}$ \\
\hline $\mathrm{EU}$ & 184.6 & 43.4 & 64.3 & 12.5 \\
\hline $\mathrm{EK}$ & 281.4 & 54.4 & 76.9 & 13.3 \\
\hline $\mathrm{EP}$ & 312.6 & 53.6 & 83.1 & 14.1 \\
\hline $\mathrm{Q} / \mathrm{A}_{\mathrm{f}}$ & 274.5 & 49.6 & 79.6 & 17.4 \\
\hline
\end{tabular}

The calculated final energy demand decreased by $72 \%$. A slightly higher energy consumption after thermal modernization was observed in relation to the determined final energy demand. The previous inspection of thermal insulation works did not show errors, also the temperatures prevailing during the research were not significantly different from those used for calculations. Perhaps the cause of excessive energy consumption was frequent airing of rooms due to poor air quality.

\section{Evaluation of the indoor environment conditions after thermal modernization}

The research on the condition of the indoor microclimate was carried out in buildings before and after thermal modernization in the same period of the heating season (during two months December, January) in similar temperature and humidity conditions outside. The research were conducted only in typical classrooms in which work was carried out during the research. The research included most of the classrooms in individual buildings. The average size of the room was $62 \mathrm{~m}^{2}$, there were about 19 persons in the room.

Many factors influencing indoor environmental quality as well as the occupants' perception of thermal comfort were considered in the evaluation. First of all, the basic thermal parameters of the microclimate were measured: air temperature $\left(t_{a}\right)$, average ambient radiation temperature $\left(t_{r a}\right)$, relative air humidity $\left(\varphi_{a}\right)$ and air velocity $\left(v_{a}\right)$. In the Table 3 are shown average values of thermal parameters of the microclimate with standard deviation value.

Table 3. Basic thermal parameters of the microclimate before and after thermal modernization.

\begin{tabular}{|c|c|c|c|c|}
\hline \multirow{2}{*}{$\begin{array}{c}\text { Parameters of the } \\
\text { microclimate }\end{array}$} & \multicolumn{3}{|c|}{ Before thermal modernization } & After thermal modernization \\
\cline { 2 - 5 } & $\begin{array}{c}\text { Arithmetic } \\
\text { mean }\end{array}$ & $\begin{array}{c}\text { Standard } \\
\text { deviation }\end{array}$ & $\begin{array}{c}\text { Arithmetic } \\
\text { mean }\end{array}$ & $\begin{array}{c}\text { Standard } \\
\text { deviation }\end{array}$ \\
\hline$t_{a},{ }^{\circ} \mathrm{C}$ & 19.2 & 2.4 & 22.4 & 1.8 \\
\hline$t_{\text {tra }},{ }^{\circ} \mathrm{C}$ & 20.7 & 2.8 & 23.8 & 1.5 \\
\hline$\varphi_{a}, \%$ & 48 & 12 & 32 & 4 \\
\hline & $\begin{array}{c}\text { Harmonic } \\
\text { mean }\end{array}$ & $\begin{array}{c}\text { Standard } \\
\text { deviation }\end{array}$ & $\begin{array}{c}\text { Harmonic } \\
\text { mean }\end{array}$ & $\begin{array}{c}\text { Standard } \\
\text { deviation }\end{array}$ \\
\hline$v_{a}, \mathrm{~m} / \mathrm{s}$ & 0.25 & 0.11 & 0.14 & 0.03 \\
\hline
\end{tabular}

The air temperature in the rooms before thermal modernization was on average $19.2^{\circ} \mathrm{C}$ with the standard deviation equal to $2.4^{\circ} \mathrm{C}$. A lower temperature value was noted at the windows, which were leaky. After thermal modernization in the rooms an increase in air temperature was noted (table 3 ). There was no significant temperature drop near the windows area. The temperature difference between the level of head and feet was bigger before thermal modernization and it was around $2.4^{\circ} \mathrm{C}$. After thermal modernization this temperature difference did not exceed $1.0^{\circ} \mathrm{C}$. The temperature near the floor did not differ by more than about $1.2^{\circ} \mathrm{C}$ from the average air temperature designated for a given room. The outside temperature during the study was on average between $-9.5^{\circ} \mathrm{C}$ and $-0.5^{\circ} \mathrm{C}$. 
The ambient radiation temperature before thermal modernization was about $1.5^{\circ} \mathrm{C}$ higher than the air temperature, just like after thermal modernization. After thermal modernization works average value of ambient radiation temperature was on level $23.8^{\circ} \mathrm{C}$. The outside relative humidity during the study was on average between $69 \%$ and $86 \%$. Before thermal modernization a higher air relative humidity level was found. The value of the air humidity ranged from 30 to $60 \%$ and amounted to an average of $48 \%$. During the day there was a gradual increase in the humidity value by about $10 \%$. The value of the air humidity noticeably decreased after thermal modernization. A considerable air humidity level in the building in connection with low thermal insulation of building envelope is related with the growth of microorganisms on their internal surfaces. Growth of moulds on the surfaces of walls within the area of window occurring sometimes before thermal modernization was completely eliminated after thermal modernization. The air velocity in the rooms was slightly higher before thermal modernization, especially near leaky windows. After thermal modernization air velocity was maintained at a relatively low level around $0.1 \mathrm{~m} / \mathrm{s}$ and did not exceed $0.2 \mathrm{~m} / \mathrm{s}$.

High carbon dioxide concentrations have a negative impact on the human well-being and health [20]. The correct level is 450-1000 ppm. By the level $2000 \mathrm{ppm}$ poor air quality and sleepiness is already observed. At values $2000-5000 \mathrm{ppm}$ the headaches are possible. Value over $5000 \mathrm{ppm}$ leads to discomfort and rapid heart rate, over 15,000 ppm to problems with breathing and over $30,000 \mathrm{ppm}$ to dizziness and indisposition. Concentration above $60000 \mathrm{ppm}$ may cause a blackout [21]. The highest permissible concentration $\mathrm{CO}_{2}$ in the work environment is $90.00 \mathrm{mg} / \mathrm{m}^{3}$ i.e. about $5000 \mathrm{ppm}$.

The mainly source of indoor carbon dioxide pollution was the rooms users breathing. During the day classes in educational buildings are periodically used and during the breaks, intensive airing of rooms occurs by opening windows. The carbon dioxide concentration in the classrooms changed dynamically depending on the number of people, the size of the rooms and the frequency of their airing. The measurement of carbon dioxide concentration was made only in two buildings. A disturbing phenomenon was observed. Although before the thermal modernization the $\mathrm{CO}_{2}$ level did not exceed $1400 \mathrm{ppm}$, after thermomodrization a maximum of $2307 \mathrm{ppm}$ was noted at the end of the work.

Fig. 1. shows the change in the concentration of carbon dioxide (in ppm) in the air in the classroom during the working day, in the educational building in which the thermal modernization was carried out.

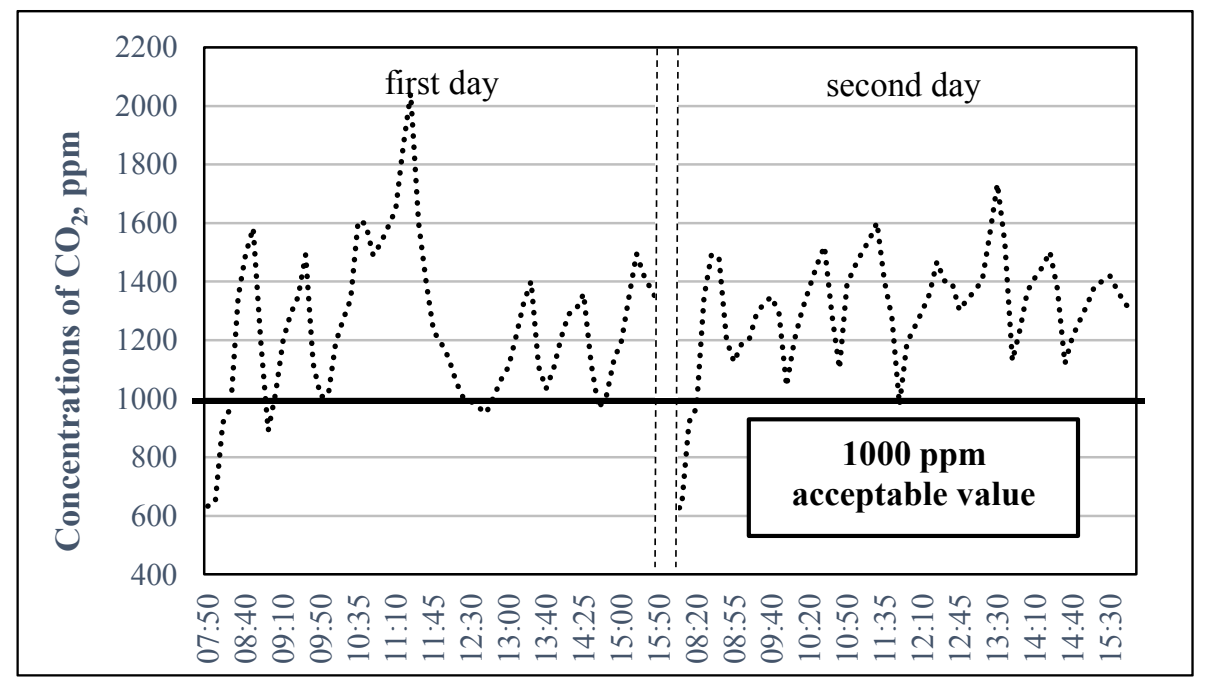

Fig. 1. Distribution of concentrations of carbon dioxide in the air. 
The initial carbon dioxide content in the air was about 600-800 ppm when the room were used daily. When the room were not used for a longer period, the concentration of carbon dioxide dropped below $500 \mathrm{ppm}$. After the start of the lesson, intensive growth of carbon dioxide was observed. Within an hour, this increase was on average 500-600 ppm and even up to $1000 \mathrm{ppm}$. The largest measured $\mathrm{CO}_{2}$ value in this room was $2043 \mathrm{ppm}$, which significantly exceeded the proper acceptable value. Intensive airing of the rooms caused a rapid drop in $\mathrm{CO}_{2}$ levels. Increasing the number of air exchanges in rooms will reduce the level of $\mathrm{CO}_{2}$ pollution [22]. During the study the value of outside carbon dioxide fluctuated in the range from $438 \mathrm{ppm}$ to $456 \mathrm{ppm}$.

During the research, the sick building syndrome symptoms were noted in people staying in the rooms, which they identified with long-term staying in a given environment. The study was based on questionnaires filled out by 189 persons before thermal modernization and 207 after thermal modernization. The occurrence of symptoms in the studied population of people before and after thermal modernization is presented in Table 4.

Table 4. Sick building syndrome symptoms before and after thermal modernization.

\begin{tabular}{|c|c|c|}
\hline \multirow{2}{*}{ Sick building syndrome symptoms } & \multicolumn{2}{|c|}{ Percent symptom occurrence } \\
\cline { 2 - 3 } & Before & After \\
\hline Headache & 32.1 & 33.8 \\
\hline Throat irritation, cough & 26.1 & 38.8 \\
\hline Malaise & 24.6 & 52.1 \\
\hline Fatigue and sleepiness & 21.3 & 45.5 \\
\hline Nose irritation, rhinitis & 24.8 & 11.3 \\
\hline Difficulty in concentration & 17.7 & 43.8 \\
\hline Eye irritation & 26.4 & 17.8 \\
\hline Irritability & 7.3 & 6.2 \\
\hline Flu-like symptoms & 41.5 & 14.4 \\
\hline Itching and dry skin & 3.4 & 1.2 \\
\hline
\end{tabular}

Some of the sick building syndrome symptoms such as above all flu-like symptoms or nose irritation and rhinitis partly receded after thermal modernization. Increased fatigue, sleepiness, malaise and difficulty in concentration which may be related with the growth of level of carbon dioxide. Generally poor air quality in the room have been reported on the about $90 \%$ people staying in rooms. The feeling of lack of fresh air created the necessity of additional airing of rooms by opening windows. During the heating season, this was the reason for the increase in heat loss and temporary deterioration of thermal comfort conditions, due to the lowering of the room temperature and the increased speed of the cold air flow.

\section{Conclusions}

The realization and exploitation of buildings consumes about $40 \%$ of total energy consumption in the European Union [5]. Thermal protection of buildings is directly related to, but not only to, energy saving. The purpose of thermal protection should also be to ensure proper conditions for the interior microclimate and thermal comfort of people staying in in closed rooms. However, attention is paid to the deterioration of indoor air quality in rooms in relation to the tightening of the thermal protection requirements of buildings associated with the energy efficiency program.

Increasing thermal insulation of buildings envelope and modernization of the heating system and hot water preparation significantly improved the energy efficiency of educational buildings. Thermal modernization activities partly improved also indoor microclimate conditions and thermal comfort perception of occupants as well as contributed to the 
elimination of some health problems related with sick building syndrome. The air relative humidity decreased, even down to the value unacceptable fully by respondents. Furthermore, the moulds growth in the area of window occurring before thermal modernization, was totally eliminated.

However after thermal modernization, the intensification of some symptoms of sick building syndrome was found, which the occupants related with worsening of air quality in the rooms. A significant increase in carbon dioxide concentration after prolonged use has also been noted. Also recorded a significant increase in the concentration of carbon dioxide after a longer time of rooms use. Probably the ventilation of rooms was not sufficient. It would be beneficial to introduce a constant, gradual inflow of fresh air in the amount necessary to ensure adequate hygienic and health conditions. This would eliminate the need for frequent ventilation by opening windows, contributed to reducing heat losses and improving the thermal comfort conditions of people staying in the rooms. But this is not possible with gravity ventilation.

In order to get a more complete picture of the initially observed phenomena, a long-term monitoring of the conditions prevailing in the rooms should be carried out.

\section{References}

1. Energy, Statistical Information and Elaborations, Central Statistical Office, Warsaw (2018)

2. EUROPE 2020. A strategy for smart, sustainable and inclusive growth, European Commission, Brussels (2010)

3. Energy 2020. A strategy for competitive, sustainable and secure energy, European Commission, Luxembourg (2011)

4. Directive 2018/844/EU of The European Parliament and of the Council of 30 May 2018 amending Directive 2010/31/EU on the energy performance of buildings and Directive 2012/27/EU on energy efficiency (2018)

5. A. Guła, The strategy of thermal modernization of buildings. Roadmap 2050 (Institute of Environmental Economics, Cracow, 2014)

6. Y. Al Horr, M. Arif, M. Katafygiotou, A. Mazroei, A. Kaushik, E. Elsarrag, Int. Jour. of Sus. Bu. Env. 5, 1, 1-11 (2016)

7. Indoor air pollutants: exposure and health effects, EURO Reports and Studies, World Health Organization (1984)

8. Economic cost of the health impact of air pollution in Europe: Clean air, health and wealth, World Health Organization (2015)

9. Sick building syndrome, World Health Organization Regional Office for Europe (1998)

10. WHO guidelines for indoor air quality: dampness and mould, World Health Organization (2009)

11. WHO guidelines for indoor air quality: selected pollutants, World Health Organization (2010)

12. Evolution of WHO air quality guidelines: past, present and future, World Health Organization (2017)

13. P. Kapalo, N. Spodyniuk, Effect of the variable air volume on energy consumption case study (IOP Conf. Series: Materials Science and Engineering 415, 2018)

14. J. Sowa, Izol. 23, 2, 76-82 (2018) 
15. J. Sowa, Jakość powietrza w budynkach energooszczędnych ([W]: Budownictwo energooszczędne w Polsce - stan i perspektywy, Red.: M. Wesołowska, Wydawnictwo Uczelniane Uniwersytetu Technologiczno-Przyrodniczego, Bydgoszcz, 155-166, 2015)

16. K. Januszkiewicz, Budownictwo o zoptymalizowanym potencjale energetycznym 2, 20 , 43-50 (2017)

17. Regulation of the Minister of Infrastructure of $12^{\text {th }}$ April 2002 on technical conditions, which should correspond to the buildings and their location (consolidated version: OJ 2015 item. 1422, as amended OJ 2017 item. 2285)

18. A. Lis, A. Ujma, Aspekty poprawy charakterystyki energetycznej budynków ([W]: Współczesne problemy budownictwa. Rozwiązania praktyczne i numeryczne. Monografie nr 330. Red.: M. Major, J. Selejdak. Częstochowa Wydawnictwo Politechniki Częstochowskiej, 213-222, 2017)

19. P. O. Fanger, Z. Popiołek, P. Wargocki, Środowisko wewnętrzne. Wplyw na zdrowie, komfort $i$ wydajność pracy (Politechnika Śląska, Gliwice, 2003)

20. P. Kapalo, F. Domniţa, C. Bacoţiu, N. Spodyniuk, Jour. of Appl. Eng. Scien. 8, 21, 61-66 (2018)

21. P. Kapalo, A. Sedláková, D. Košicanová, O. Voznyak, J. Lojkovics, P. Siroczki, Effect of ventilation on indoor environmental quality in buildings (The $9^{\text {th }}$ International Conference on Environmental Engineering Selected Papers, Vilnius, VGTU Press, 1-6, 2014)

22. S. Vilcekova, P. Kapalo, L. Meciarova, E. Krídlová Burdová, V. Proc. Eng. 190, 496-503 (2017) 